\title{
PENGARUH KELOMPOK TEMAN SEBAYA (PEER GROUP) TERHADAP PERILAKU BULL YING SISWA DI SEKOLAH
}

\author{
Dara Agnis Septiyuni ${ }^{1}$, Dasim Budimansyah ${ }^{2}$, Wilodati $^{3}$ \\ 1SMA Negeri 2 Tasikmalaya \\ 2Dosen Program Studi Pendidikan Sosiologi \\ ${ }^{3}$ Dosen Program Studi Pendidikan Sosiologi
}

\begin{abstract}
ABSTRAK
Penelitian dilakukan untuk mengetahui apakah kelompok teman sebaya berpengaruh terhadap terjadinya perilaku bullying siswa di sekolah. Penelitian bertujuan untuk mengetahui gambaran umum mengenai kelompok teman sebaya, perilaku bullying siswa, dan pengaruh kelompok teman sebaya terhadap terjadinya perilaku bullying siswa. Hasil penelitian menunjukkan bahwa siswa SMA cenderung mempertimbangkan kesamaan yang dimiliki, sebagian besar siswa SMA pernah melakukan perilaku bullying baik secara verbal, fisik maupun psikis, dan kelompok teman sebaya berpengaruh secara positif dan signifikan terhadap perilaku bullying siswa di SMA Negeri di Kota Bandung dengan koefisien korelasi sebesar 0,360 dan $\rho<0,05$, serta koefisien determinasi sebesar 13\%. Hal ini menggambarkan bahwa sebanyak $13 \%$ dari variabel dependen dipengaruhi oleh variabel independen.
\end{abstract}

Kata kunci : kelompok sebaya, perilaku bullying, siswa SMAN.

\section{PENDAHULUAN}

Kasus bullying yang sering dijumpai adalah kasus senioritas atau adanya intimidasi siswa yang lebih senior terhadap adik kelasnya baik secara fisik maupun non-fisik. Bullying atau penindasan adalah penggunaan kekerasan atau paksaan untuk menyalahgunakan atau mengintimidasi orang lain.

Kasus bullying di Indonesia seringkali terjadi di institusi pendidikan. Hal ini dibuktikan dengan data dari Komisi Nasional Perlindungan Anak, tahun 2011 menjadi tahun dengan tingkat kasus bullying tertinggi di lingkungan sekolah yaitu sebanyak 339 kasus kekerasan dan 82 diantaranya meninggal dunia (Komnas PA, 2011).
Para ahli menyatakan bahwa school bullying merupakan bentuk agresivitas antarsiswa yang memiliki dampak paling negatif bagi korbannya (Wiyani,2012, hlm 16).

Perilaku bullying merupakan perilaku agresif yang serius. Perilaku agresif dapat terjadi karena berbagai faktor. Faktor-faktor situasional yang dapat memicu terbentuknya perilaku agresif menurut O'Connell (dalam Annisa, 2012, hlm 3) antara lain budaya sekolah (bullying yang dilakukan guru atau teman sebaya), teknologi dan norma kelompok.

\section{GAMBARAN KELOMPOK SEBAYA}

Pada dasarnya manusia memiliki dua hasrat utama yaitu keinginan untuk bersatu dengan masyarakat dan keinginan untuk bersatu dengan alam 
sekitarnya, oleh karena itu kemudian dibentuklah kelompok-kelompok sosial yang menempatkan individu bersama dengan orang-orang disekelilingnya untuk memenuhi keinginan tersebut.

Kelompok teman sebaya sebagai lingkungan sosial bagi remaja (siswa) mempunyai peranan penting bagi perkembangan kepribadiannya, salah satunya untuk mengembangkan identitas diri serta mengembangkan kemampuan komunikasi interpersonal dalam pergaulan dengan kelompok teman sebaya.

Memiliki beberapa persamaan adalah salah satu kriteria dalam pembentukan kelompok sebaya. Terbukti dari hasil penafsiran angket penelitian tentang karakteristik teman sebaya yang memiliki rata-rata jawaban sebesar 3,27 dan termasuk dalam kategori sering. Hasil tersebut memberikan kesimpulan bahwa sebagian besar responden selalu berkelompok dengan siswa lain yang memiliki persamaan usia, minat, dan keinginan. Sebagian besar responden menyatakan sering berkelompok dengan siswa yang berasal dari tingkatan kelas yang sama. Dengan demikian dapat disimpulkan bahwa dalam berkelompok responden mempertimbangkan persamaan usia, persamaan keinginan, persamaan minat serta tujuan yang sama.

\section{GAMBARAN PERILAKU BULLYING SISWA}

Perilaku bullying merupakan salah satu bentuk kenakalan remaja atau juvenile delikuensi karena perilaku tersebut melanggar norma masyarakat. Perilaku bullying sendiri termasuk ke dalam perilaku menyimpang yang dilakukan oleh remaja terhadap sesamanya yang menurut sudut pandang sosiologi dapat disebabkan oleh pengaruh struktur sosial yang deviatif, tekanan kelompok, peranan sosial, status sosial atau oleh internalisasi simbolis yang keliru (Kartono, 2013b, hlm. 28).

Bullying merupakan salah satu bentuk perilaku agresi. Ejekan, hinaan, dan ancaman yang seringkali merupakan pancingan yang dapat mengarah pada tindakan agresi (Widayanti, 2009, hlm. 2). Tiga kategori praktek bullying yaitu : (a) bullying fisik, (b) bullying non fisik / verbal dan (c) bullying mental atau psikologis. Faktor penyebab terjadinya bullying yaitu faktor eksternal dan internal. Faktor internal adalah : (a) karakteristik kepribadian (b) kekerasan pada masa lalu dan (c) sikap orangtua yang memanjakan anak sehingga tidak membentuk kepribadian yang matang. Faktor eksternal adalah lingkungan sosial dan budaya (Hoover 1998, dalam Simbolon, 2012, hlm.235).

Berdasarkan hasil penelitian dan penafsiran angket, hampir sebagian besar responden pernah melakukan tindakan bullying, baik bullying secara verbal, bullying secara fisik, maupun bullying secara psikis. Sedangkan intensitasmya masing-masing bullying secara verbal berada pada kategori jarang/rendah, bullying secara fisik juga berada pada kategori jarang/rendah, dan bullying secara psikis berada pada kategori kadangkadang/cukup.Namun berdasarkan skor rata-rata yaitu bullying secara psikis sebesar 2,14, kemudian bullying 
secara fisik sebesar 1,92, dan bullying secara verbal sebesar 1,80. Dari hasil tersebut dapat disimpulkan bahwa responden dalam melakukan tindakan atau perilaku bullying berdasarkan frekuensinya cenderung lebih sering melakukan bullying secara psikis.

\section{PENGARUH KELOMPOK SEBAYA TERHADAP PERILAKU BULLYING SISWA}

satu faktor yang mempengaruhi perilaku bullying siswa di sekolah adalah pergaulan

Dari hasil penelitian ini diperoleh data yang bersumber dari kuesioner yang disebar kepada 100 responden yang merupakan siswa SMA yang berasal dari tiga SMA negeri yang berbeda di kota Bandung. Data tersebut kemudian dgunakan untuk menganalisis koefisien korelasi, signifikansi, dan koefisien determinasi. Analisis tersebut digunakan untuk membuktikan apakah kelompok teman sebaya berpengaruh terhadap terjadinya perilaku bullying siswa di sekolah.

Hasil perhitungan statistik menunjukkan bahwa korelasi antara kelompok teman sebaya dan perilaku bullying adalah positif dan signifikan dengan nilai koefisien korelasi sebesar 0,360 dan nilai $\rho<0,05$. Maka dapat disimpulkan bahwa hipotesis yang diajukan yaitu "kelompok teman sebaya berpengaruh terhadap terjadinya perilaku bullying siswa di

\section{DAFTAR PUSTAKA}

Annisa. (2012). Hubungan antara Pola Asuh lbu dengan Perilaku Bullying Remaja. Skripsi Sarjana, Universitas Indonesia. Depok. sekolah" dapat diterima dan telah diuji keberartiannya. Untuk mengetahui besarnya pengaruh kelompok teman sebaya terhadap perilaku bullying siswa maka dilakukan analisis koefisien determinasi. Dari hasil perhitungan didapatkan nilai koefisien determinasi sebesar $13 \%$ yang menggambarkan bahwa sebesar $13 \%$ perilaku bullying siswa di sekolah dipengaruhi oleh kelompok teman sebayanya. Sedangkan sisanya sebesar $87 \%$ dipengaruhi oleh faktor lain, yakni pola asuh orang tua, harga diri, lingkungan sekolah, dan media.

\section{PENUTUP}

Kelompok teman sebaya siswa di sekolah adalah kelompok yang terbentuk di dalam lingkungan sekolah berdasarkan persamaan usia, tingkatan kelas, minat atau hobi yang sama, serta tujuan yang sama. Perilaku bullying merupakan tindakan delikuen remaja yang secara sosiologis disebabkan oleh pergaulan remaja dengan lingkungan sosialnya.

Berdasarkan hasil analisis data dan pengujian hipotesis, ditemukan fakta bahwa kelompok teman sebaya menjadi salah satu faktor penyebab terjadinya perilaku bullying siswa di sekolah. Dengan nilai korelasi sebesar 0,360 dan $\rho<0,05$ artinya kelompok teman sebaya berpengaruh terhadap terjadinya perilaku bullying siswa di sekolah, dengan kontribusi pengaruh sebesar $13 \%$.

Kartono. K. (2013b). Patologi Sosial 2 : Kenakalan Remaja. Cetakan ke 11. Jakarta : Rajawali Pers.

Simbolon, M. (2012). Perilaku Bullying Pada Mahasiswa Berasrama. 
Jurnal Sosietas, Vol. 5, No. 1

Jurnal Psikologi, 39 (2), hlm. 233243.

Widayanti, C.G. (2009). Fenomena bullying di sekolah dasar di Semarang. Jurnal Psikologi Undip, 5 (2), hlm. 1-13

Wiyani, N.A. (2012). Save our Children from School Bullying. Jogjakarta : Ar-Ruzz Media 